\title{
The new EU Directive 2014/26 as a catalyst for film and digital content innovation in Europe
}

Loreto Corredoira y Alfonso

Professor of Communication Law

loretoc@ucm.es

Universidad Complutense de Madrid, Facultad de Ciencias de la Información

Av. Complutense, s/n. Ciudad Universitaria. 28040 Madrid, España

loretoc@ucm.es

http://orcid.org/0000-0003-1198-7659

\begin{abstract}
:
The present paper analyses various conditions of the digital content market, such as barriers to competition and bottlenecks to intellectual property (IP) rights generation and management, as well as the collective copyright management system. The paper will discuss the need to modernize Spanish IP law, improve the transparency of how "collecting societies" operate and liberalise processes for licensing and transferring IP to allow for new types of contracts. It will also explore how regulatory reform en route to a digital single market stands to give more freedom to copyright holders and producers, and how Directive 2014/26 is likely to affect music and other paid contentsectors such as film and video. It argue that these reforms will open new business opportunities in entertainment, as well as offer solid alternatives to piracy, which may help revitalise the digital content industry in Europe.
\end{abstract}

\section{Text}

In this specialissue of the Journal, scholars analyse different aspects of the new Directive $2014 / 26^{1}$ of 26 February 2014, which must be implemented by transposition into national legislations no later than 10 April 2016. The Directive reflects several goals stipulated in the European Commission's Digital Agenda for Europe ${ }^{2}$, published in 2010, particularly the objective of creating a vibrant digital single market. Key to the creation of such a market is achieving a rational reform of the copyright regime. As the Commission itself announced in its 2012 report On Content in the Digital Single Market $^{3}$,the goal is to ensure that copyright and copyright-related practices, such as licensing, stay fit for purpose in this new digital context.

Therefore many are watching with interest to see how national IP laws and business models for sharing digital content will co-evolve in line with the Directive and thereby coalesce into a digital unified market that will work seamlessly to the benefit of industry and consumers alike. I will discuss these and other related questions from the perspective of a researcher just back from a sabbatical at the University of California at Los Angeles, where I examined how Hollywood has been adapting its marketing and 
legal framework to the new realities of on-demand digital content sharing, such as the Netflix platform and transactional platforms such as iTunes ${ }^{4}$.

The Directive has the potential to catalyze profound change in film distribution in Europe, where only approximately $15 \%$ of all films produced are currently available through online legal platforms 5 . To be sure, part of this lack of "technical access or availability" reflects linguistic and cultural differences within Europe and between Europe and other continents, making many films and TV shows difficult to market successfully in other countries. Nevertheless, most experts (Villanueva, 2012; Sood\&Corredoira\&García-Ugellés, 2015, Hargreaves, 2011) agree that the primary obstacle to online distribution is lack of appropriate business models and copyright regimes, which the new Directive aims to address. In this sense, the Directive may encourage and facilitate cross-border sharing of digital content, which benefits producers by increasing their market and users by expanding their access to international content. This applies immediately to music and, depending on how the Directive is implemented and interpreted, it may also apply to audiovisual content more broadly. This easier access to content abroad may help combat piracy, which is one of the goals behind the single digital market, since "delayed legal availability of the content abroad may drive the losses to piracy", as Danaher and Waldfogel (2012) have commented about the US, and since piracy in Spain appears to be driven by "availability and price" (Dans, 2014 March). I certainly hope that the Directive is as effective as possible at providing the same unified-market opportunities for music, films and TV shows.

Taking Spain as a case study, the present paper will analyse some conditions of the digital content market, such as barriers to competition and bottlenecks to IP rights generation and management, as well as the collective copyright management system. I will focus on how the IP regime for the audiovisual digital market will need to evolve to keep up with technological advances. In particular, I will discuss four issues: (1) the need to modernise IP law; (2) what are the barriers to competition in the current IP collective management system in Spain, particularly the rigid functioning of "collecting societies", which have been accused of lack of transparency and excessive control, and which prevent the possibility of new contract types; (3) how regulatory reform to produce a digital single market will bring more freedom for copyright holders and producers; and (4) what effects Directive 2014/26 is likely to have on music and other paid content-sectors such as film and video.

The hypothesis the paper propose is that introducing certain legal reforms and new contractual practices at EU and national levels will open many new business opportunities in film and entertainment. Innovating the IP regime would offer solid alternatives to piracy, which may help revitalise the digital content industry in Europe, which has been suffering stagnation, if not shrinkage, over the last several years. This stagnation is strongly affecting employment, according to a 2013 report from the Heads of State of the $\mathrm{EU}^{6}$. Increasing employment, then, is one more argument for modernising Europe's copyright regime.

\section{From an incomplete, ad hoc IP system to a modern, standardised one}




\subsection{Content creators, editors and distributors at the heart of IP law}

For many centuries, Western cultures have protected creation; thus, authorship lies at the centre of IP law. Though different legal codes may adopt different terminology such as "copyright law" in the US", "the rights of authors in their literary and artistic works" in the Berne Convention ${ }^{8}$, or "intellectual property" in the French" or Spanish IP Laws - the key to implementing and reforming IP law is understanding how it defines those rights and how those definitions align with the new realities of digital content sharing. In addition to protecting the "author/creator" of content, IP law since the 19th century has also defined and protected the rights of producers and publishers. For example, the Spanish law on IP (Royal Decree $1 / 1996^{10}$, subsequently referred to as Spanish IP Law to refer to the most recent version) dealt with both kinds of creative rightholders in separate sections, one for author's rights (Articles 1-104) and the other for related IP rights (Articles 105-137). Both types of rights remain essential in the new era of digital content. It can even be argued that producers enjoy an increasing presence in the "digital market" since they make possible the electronic distribution essential for market penetration. The growing importance of content editors and distributors in IP rights management makes it difficult for content creators or authors to engage in alternative types of licensing, since they are obliged to cede their IP rights to editors and distributors.

Current IP law in Europe is incomplete, ad hoc and at times chaotic. Depending on the country and digital content in question, national laws may be lacking, laws may exist but are unenforced, or the enforcement regimes may be ineffective. Conversely, IP law may be too effective: in the name of preventing privacy, national regulations block legitimate possibilities for digital content sharing.

National responses to the challenge of piracy in the digital era have been diverse (Table 1). Some countries have already passed specific laws that guarantee the application of adequate sanctions for copyright violations (France, Colombia, Spain, Brazil, US), while other countries continue efforts to amend existing laws or draft new ones (Canada, UK, Spain, US). These sometimes divergent national approaches have led to significant differences in IPR enforcement. In Spain, for example, "fair use" is interpreted according to EU Directive $2007 / 65^{11}$, where it is defined in a more limited way than in US law. As a result, "domestic copying" is permitted in Spain.

The EU has clearly established anti-piracy efforts as a priority. EU Directive 2004/48 ${ }^{12}$ (Article 8.1) requires all member states to identify, via judicial order, those who infringe on IPRs (Ordoñez, 2011) ${ }^{13}$. In addition, the Directive stipulates that "Member States shall ensure that, in the context of proceedings concerning an infringement of an intellectual property right and in response to a justified and proportionate request of the claimant, the competent judicial authorities may order that information on the origin and distribution networks of the goods or services which infringe an intellectual property right be provided by the infringer and/or any other person ... c) found to be providing on a commercial scale services used in infringing activities".

TABLE 1 here 
On 30 December 2011, the Spanish government introduced a legal procedure to delete content that infringes copyright law, and it reformed the Intellectual Property Commission. The Spanish Council of Ministers repealed the controversial "digital canon," a tax that every user had to pay as compensation for fair use of a copyrighted work. On the same day, the government of Spain approved a decree enacting the "Sinde-Wert Act", named for former Minister of Culture Angeles González Sinde, which Parliament had passed in March of that year. This law paved the way to implementing a new process for deleting illegal content on Spanish servers or sites hosted on Spanish territory. Some media commentators have called the Sinde Act a Spanish SOPA Law.

In the UK, the Digital Economy Act calls for a graduated response to IPR infraction that begins with identifying the potential IPR violator and issuing a series of warnings. Minero $\left(2013^{14}\right)$. The Digital Economy Act envisions not only graduated warnings but also a graduated system of penalties. ${ }^{15}$

Indeed, in many countries, associations of communication users, associations of internet users, the Anonymous movement and the \#AntiCanon movement have complained that copyright and anti-piracy laws punish the sharing of creativity and openness of the Internet. Spain is one of the countries that have gone down this road. The government continues to follow a strategy of "hyper-regulation" and control of the digital economy in order to foster innovation. For example, it recently approved ${ }^{16}$ the incorrectly named "Google tax", which is a surcharge for aggregating digital news. The controversy surrounding this tax reminds me of the concept of a "co-creation" culture, given the gray area dividing content users and creators in media and blogs (Picard \& De los Angeles, 2014). New methods of digital content creation have led to a more collaborative culture that does not easily fit within the classical conception of authorship.

Some media colleagues, scholars and I have previously expressed our views on such collaboration, which we continue to analyse in our on-going research project about the survival of digital journalism in the digital economy (Garcia Torres et al, 2013). This work suggests that the way to incorporate readers and users of digital media into such collaborations is to recognise their rights to copyright and apply best practices to generation of web content.

\subsection{A New IP management models for creative industries}

To avoid suppression of creativity, some countries have sought to define new ways to regulate IP, including The Hargreaves Review ${ }^{17}$ (Hargreaves, 2011) to update the UK Copyright $\mathrm{Act}^{18}$, the Hadopi Loi in France ${ }^{19}$ and the Sinde Law ${ }^{20}$ in Spain. Most of these laws have been incomplete successes in the best case, highlighting that we still have a long way to go to strengthen IP protection in Europe while also fostering innovation and adoption of new business models for sharing digital content. The challenge, in the words of the previous EU Commissioner Michel Barnier ${ }^{21}$, "is to establish new models of use and distribution which allow the creativity, efforts made and risks taken to be appropriately rewarded". 
Collective experience with these laws has led, in my opinion, to a shift towards favouring new business models for content sharing in the EU (Corredoira, 2014, Minero\&Ramón 2012), the latest expression of which is the new Directive 2014/26. This Directive, for example, stipulates a new way to manage multiterritorial licenses for music creation. This licensing system is envisaged for music as well as audiovisual works that include music, such as videogames and movies. The Directive mandates (Titles III, Articles 23-32) that certain IP rights be managed through collective entities, which include agencies authorised to reproduce and disseminate creative works. The Directive also describes circumstances under which collective entities are free to transfer reproduction and distribution rights to other agencies. These situations would include, for example, increasing the availability of a film title in parallel with its projection in cinemas (windows of exploitation), allowing a user to travel with his or her digital TV subscription elsewhere in Europe, or allowing a purchaser of movies from iTunes or other portals to access the content from another country or IP address.

The Directive establishes the freedom of rightholders to choose their collective management organisations, mandates that different types of rightholders (e.g. authors or producers) be treated equally under the law, and requires equitable distribution of royalties (Title II, Article 5). These measures may help foster the development and expansion of creative industries like Spotify, Filmin, Pandora, Netflix or Amazon Prime; resolve current challenges to equal compensation of IP creators and artists; and help optimise the contractual framework for content intermediaries, such as companies like Netflix, Spotify and Filmin, as well as small concerns like music downloading sites, all of which are effectively "users" that must enter into licensing agreements with collective societies to be able to exploit the content for different purposes.

The Directive may well liberalise several creative industries and render them more dynamic and adaptable in the face of exponentially changing technology for content generation and dissemination. It may provide additional freedom from monopolies to producers and distributors of on-line music, movies and news, allowing innovators to sell, rent, or licence their IP rights as they wish. Such freedom does not exist in Spain under the collective management system ${ }^{22}$. Unfortunately the Directive will not enter into force until April 2016, but when it does, it may render many creative industries more dynamic.

At the very least, it should create more collaboration and data sharing among IP stakeholders. IP organisations, independent agencies and law offices will need to interact and exchange information constantly in order to open new markets and flexibly manage creative products, which have a life of their own.

My aspiration for the Directive in particular, and the European IP regime in general, is that they foster freedom, flexibility and innovation in managing author's rights without compromising the rights of "creators" (e.g. journalists, photographers) or users. Media industries need a "new creativity law" (Picard \& De los Angeles, 2014). This will require a coherent and comprehensive approach that lives up to the promises of the previous Commissioner Michel Barnier during the launch of the initiative "Licences for Europe" (European Commission, 2013): "The internet must offer Europeans the widest possible access to the quality content which they are so eager to have; however, the digital universe must also give rise to new forms of contractual relations between the various stakeholders contributing to its development; web entrepreneurs must also be able to draw on the single market to launch innovative services, and lastly, a good level 
of certainty must be guaranteed for Internet users who tap into its creative potential and for content distributors".

The Directive certainly aims to be ambitious, setting out rules and recommendations for the full range of IP stakeholders, including authors, artists, collecting societies, editors and producers, media groups, Internet platforms, online service operators and, of course, consumers. For these various groups, the Directive aims to transform the copyright from obstacle to instrument of market flexibility and innovation in order to ensure crossborder portability of services, such as the mechanisms laid out for transnational sharing of music; guarantee the mobility of services and content between different devices and different national networks when users move around Europe; increase the amount of online content available (film, TV series, documentaries); and foster affordable licensing schemes for end users and intermediaries.

In other words, the Directive and the shift in IP thinking that we believe it represents should promote efforts by politicians and industry to satisfy users willing to pay to see content other than the usual blockbusters, as well as younger generations that use illegal peer-to-peer (P2P) sites. These sites enable content exchange between users; Napster was the first such site for music and it remained one of the more popular P2P sites until it closed down in July 2001.

\section{Barriers to competition and other dysfunctionalities in IP law: the case of Spain}

It is worthwhile examining the current state of IP law in Spain because it provides a clear example of an IP environment that stands to benefit significantly from Directive 2014/26 and the shift in IP thinking that it represents. One of the most important determinants of the IP situation in the country is also one of the most controversial among legal scholars (Marín López, 2007)(Vinje \& Nllranen, 2005) and consultative bodies such as the National Commission on Competition (CNC in Spanish), the Economic and Social Council and the State Council: the de facto monopoly that eight collective management agencies enjoy over authors, artists and producers. As a result, the legal and practical barriers to entering the IP market pose a serious problem to competition. Another problem to competition is the legal requirement that certain IP rights be managed collectively through an agency (green boxes in Figure 1), which prevents authors or other rightholders from working in alternative ways, such as through individual contracts. In 2009 , the $\mathrm{CNC}^{23}$ provided a detailed explanation for why certain rights have to be managed collectively.

\section{Figure 1.}

In the following sections, I will describe in detail what I consider to be dysfunctional aspects of the current Spanish IP regime. To provide some context for this discussion, I present in Table 2the various moral, financial and compensation rights defined by the IP Law in Spain for authors and other IP rightholders of audiovisual works (UTECA, $\left.2009^{24}\right)$. 
Table 2 


\subsection{Dysfunctionalities in the Spanish IP legal system: Mandatory collective management rights vs. individual rights}

The 2009 report by the CNC identified several specific deficiencies in Spanish IP legislation that the Commission believes not only make the IP regime inflexible but also hamper expansion of the online content industry. Though some of these deficiencies have improved in the years since the report was published ${ }^{25}$, the essential conclusions of the Commission remain accurate: "together with the legal entry barriers, there are strategic obstacles which collecting societies have established in a regulatory environment that allows them to exploit their monopoly position". Particularly:

- For one, it is standard practice for the contracts with foreign collecting societies to include exclusivity clauses in the management of repertoires and obstacles to the rightholders' free choice of society.

- In addition, contracts with rightholders are characterised by lengthy durations and advance notice requirements, limit the rightholder's freedom to define the scope of the contract and guarantee the society will have exclusivity in administering the rights.

- And lastly, collecting societies often establish fees that are unrelated to actual use, pool in the same repertoires rights which by law are subject to mandatory collective management with others that are not, and are markedly nontransparent in relation to their repertoires. These factors combine to strengthen collecting societies' marketpower".

Table 3, presented below, distinguishes IP rights that in Spain must be managed collectively according to Article 147-159 of the Spanish IP Law, from rights that can be managed individually.

The CNC report goes on to highlight additional problems posed by the monopolistic position of the collective management agencies. Collecting societies have substantial market power and they normally carry on their activity from a monopoly position. The eight societies existing in Spain (SGAE, DAMA, CEDRO, VEGAP, AGEDI, EGEDA, AIE, and AISGE) each specialise in administering a given category of rights that no one else manages. The lone exception is found in relation to the authors of audiovisual works, where there is a minor degree of competition between the dominant association SGAE and the minority player DAMA.

The monopoly position of collecting societies reduces their incentive to operate efficiently and opens the door to a number of problems. One is the application of unfair and/or discriminatory pricing practices. Another consists of the difficulties confronted by users of protected works to manage their costs efficiently and to develop nontraditional markets for exploiting copyrighted works.

\section{Table 3}

Directive 2014/26 will fundamentally alter the current landscape of collective rights management in Spain, rendering the IP regime more flexible and dynamic. The management agencies have always had to balance their monopolistic leverage against 
state-imposed restrictions, but the greatest change in how collective management agencies operate will likely come in 2016, when the Directive is transposed into Spanish law.

This transposition will likely need to respond to the following problems pointed out by the $\mathrm{CNC}$ in their 2009 report:

1) There is no ex-ante control of the fees set by collecting societies, whether by introducing effective obligations in this regard or through supervision by a competent authority.

2) The process by which contracts are negotiated with users does not ensure that the fees are reasonable and equitable, because when an agreement is not reached, the legal framework allows the application of the general fees preestablished unilaterally by the monopolistic society, greatly reducing its incentive to negotiate further.

3) Third, ex-post control is quite limited, mainly because the Intellectual Property Commission, set up by the Intellectual Property Act of 1987 as a mechanism for resolving pricing disputes between collecting societies and certain users, has proven ineffective for lack of necessary authority and coercive powers.

Some of the problems identified by the competition authorities prevent rightholders from managing their rights individually, forcing them to obtain these services from a collecting society. This creates a captive demand for collecting societies, which hold a monopoly position and guarantees that societies act as legal representatives of rightholders in all disputes.

This arrangement can give rise to agency problems between the rightholder and the collecting society, which appear when there are conflicts of interest between the agent (the collective manager) that provides services and the rightholder. Subsequent problems may arise during negotiations or in the setting of fees. For example, the society may prolong negotiations with users beyond what a group of rightholders might be willing to accept. Another possibility is that pricing levels may not satisfy the preferences of rightholders that the society represents.

\subsection{The key right of public communication for online and mobile services}

Unblocking IP rights currently required to be collectively managed is crucial to the creation of a digital single market envisaged in Directive 2014/26 and several earlier European Commission documents. In Spain, only cable-based communication must be managed by collective entities, and this requirement stems from a specific1993 EC Directive $^{26}$, while the practice of requiring several other rights to be collectively managed (Table 2) does not reflect any EC Directive or Spanish law but rather legal tradition dating from the IP Law of 1996, which created and consolidated the system of 
eight collective entities mentioned above, ensuring them a monopolistic position in the IP system.

For example, the right to remuneration for public communication is currently required to be collectively managed (Table 3), yet this is in direct conflict with the core online business of such companies as Netflix, Spotify, Pandora and Nubeox (AtresMedia, Spain). To make IP reform more difficult, the definition of "public communication" in the Spanish IP Law clearly includes online and mobile services:

1. Public communication is defined to be any act by which several individuals can gain access to a work without having previously received copies of it. Communication is not considered public when it occurs in a strictly domestic setting without connection to any type of network.

2. In particular, acts of public communication include:

i) Making works available to the public through wired or wireless channels in such a way that anybody can access them where and when he or she wishes....

(Article 20, Royal Decree 1/1996; author's translation)

This legal situation presents serious obstacles to implementation of the service portability that is a hallmark of Directive 2014/26. The European Commission ${ }^{27}$ laid out a clear vision of portability: "The Commission's objective is to foster cross-border online access and "portability" across borders of content. To benefit from new developments, like cloud-computing, cross-border legal access to cloud-stored content and services should also be facilitated. Service providers interested in providing their services to consumers across the EU need to ensure that they have secured all the necessary rights in the Member State in which they wish to provide services. Both multiterritory and single territory licensing is possible, depending on the sector, the service provider and the rights holder. However, distribution of content is often limited to one or a few Member States (e.g. using geo-blocking), with service providers (online platforms) or rights holders electing to impose cross-border sales restrictions".

Portability has implications not just for business models but also for developing the audiovisual sector in general and the preservation and dissemination efforts of cultural heritage institutions. Here again the European Commission has called for significant change: an objective is to facilitate the deposit and online accessibility of films in the EU both for commercial purposes and non-commercial cultural and educational uses. It remains difficult for online service providers to develop catalogues of European films for online availability, particularly those which are "out-of-distribution" i.e. works whose rightsholders are unwilling or unable to exploit on an individual basis: it may be difficult to identify the existence of films, or the rights may be complex and timeconsuming to clear.

The right to remuneration for cable communication can actually be managed collectively or individually depending on the desire of the rightholder; this is enshrined in European Commission Directives 92/100 and 93/83 ${ }^{28}$. However, Spain requires collective management by virtue of its ability to regulate things not explicitly regulated 
by the Directive. The right to remuneration for IP rental, in contrast, is well established in the Spanish IP Law as a right that can be managed individually in the case of authors (Article 90.2) and artists, interpreters, and performers (Article 109.3). This is consistent with Directive 92/100. The same Directive describes the right to a single equitable remuneration for producers of phonograms and performers for the communication of phonograms to the public and does not require collective management. However, the Spanish IP Law does (Articles 108.4, 108.6, 116.2 and 116.3).

This brief analysis highlights just some of the differences between the more restrictive IP rights management in the Spanish IP Law and European Commission Directives, and these differences have intensified with the passage of Directive 2014/26. The framers of the Spanish IP Law clearly had in mind monopolistic collective management entities; otherwise, it is difficult to justify the contracting obligations imposed on the collective entities by Articles 152 and 157.1, among other parts of the law. As the CNC concluded in 2009, these factors mean that the IP Law restricts competition and reinforces entry barriers to IP rights beyond the intrinsic financial barriers, reinforcing the tendency for a few IP stakeholders to control the market. This is a particular problem in the music and entertainment market. For example, nearly $50 \%$ of revenues collected by SGAE come from only the 3 private television stations and a few radio broadcasters. In addition, the Spanish IP Law makes direct contracts between artists or performers and content distributors difficult or impossible.

\section{Possible impact of Directive 2014/26 on the online content industry in Spain}

Based on the foregoing analysis of the Spanish IP Law, I suggest that Directive 2014/26 will bring fundamental changes to the online content industry in the country and likely in other EU members states with similar IP legal frameworks. These changes will be particularly significant in the online music and film industry.

\subsection{Liberalisation of IP rights management}

The Directive will introduce more freedom into the way IP rights are created and managed in the EU, benefiting not only rightholders (producers, artists, scriptwriters, composers) but also the management of digital works, since certain rights will no longer be the exclusive purview of collective management entities. It will be interesting to see whether and how Spanish IP Law will change and with it the rights that must be collectively managed and the rights that can be managed individually (Table 3 ).

The most relevant part of the new Directive in this respect is Whereas 37:

(37)Providers of online services which make use of musical works, such as music services that allow consumers to download music or to listen to it in streaming mode, as well as other services providing access to films or games where music is an important element, must first obtain the right to use such works. Directive 2001/29/EC requires that a license be obtained for each of the rights in the online exploitation of musical works. In respect of authors, those rights are the exclusive right of reproduction and the exclusive right of communication to the public of musical works, which includes the right of making available. Those rights may be managed by the individual rightholders themselves, such as authors or music publishers, or by collective management organisations that provide collective 
management services to rightholders.

The ability of rightholders to manage their IP rights themselves would be a significant improvement over the status quo in Spain, giving individual artists the power to hold and cede their IP rights as desired. In addition, this right to individual IP management would presumably apply to commercial as well as nonprofit uses of the creative work. This may provide significant economic incentives to nonprofit activities, as illustrated in the recent case of a humanitarian concert given by the singer Bisbal in Spain, in which the collective management agency SGAE faced public backlash for charging disproportionately high fees for public use of the singer's repertory. ${ }^{29}$

The Directive will relax restrictions not just on rightholders but also on collective management entities. It will free up these entities to adopt any of several legal structures, including limited societies, cooperatives or non-profit organizations, in contrast to the Spanish IP Law, which requires these entities to be non-profits. At the same time, the Directive imposes conditions of transparency (Whereas 45) and delegation to other collective entities in territories where the first entity is not legally established (Whereas46).

(45)"The transparency of the conditions under which collective management organisations manage online rights is of particular importance to members of collective management organisations. Collective management organisations should therefore provide sufficient information to their members on the main terms of any agreement mandating any other collective management organisation to represent those members' online music rights for the purposes of multi-territorial licensing".

(46)It is also important to require any collective management organisations that offer or grant multi-territorial licences to agree to represent the repertoire of any collective management organisations that decide not to do so directly. To ensure that this requirement is not disproportionate and does not go beyond what is necessary, the requested collective management organisation should only be required to accept the representation if the request is limited to the online right or categories of online rights that it represents itself".

I consider it quite a positive development in IP regulation that the Directive, which was originally conceived for the online music sector, will reform the IP management system and collective entities for all creative industries, including books, magazines, audiovisual works, and the plastic arts. While Title III and Articles 34.2 and 38 apply only to collective entities that manage copyrights for the international, online use of musical works, Titles I, II, IV and V apply to all collective management entities.

Eight collective entities in Spain will be affected by this Directive (Table 4). The entities that will be affected specifically in their management model, transparency, price setting and representation throughout Europe are CEDRO, EGEDA, AI, AISGE, EGEDA, SGAE and DAMA. 


\subsection{Expansion of the collective management sector}

By breaking the de facto monopolies of the large collective management entities in Spain, Directive 2014/26 will expand the management sector, opening it up to the numerous smaller stakeholders in the creation, distribution and consumption of digital content on television, radio and other entertainment and media outlets. These new participants in IP rights management include so-called "on-line providers", management agencies classified as "independent operators", rightholders not currently part of collective entities as well as individual users of content (e.g. radio stations, TV stations, entertainment negotiators). On-line providers are also a kind of content user, and they are becoming increasingly relevant in the digital content industry for their key role in distributing and publicly communicating music and multimedia.

Though the explicit goal of much of the Directive is to promote the development of legal services for distributing music online, the regulation is likely to have similar effects on the distribution of other types of content as well, particularly for the streaming of audiovisual works and multimedia content. As stated in Whereas 38:

(38) "Providers of online services which make use of musical works, such as music services that allow consumers to download music or to listen to it in streaming mode, as well as other services providing access to films or games where music is an important element, must first obtain the right to use such Works".

Although the concept of multimedia work in EU law (Stamatoudi, 2002) is poorly defined, the precedent of US IP law $^{30}$ is that any work containing audio, video and text including a web page or news portal- is considered a multimedia work for the purposes of integrated rights management (Smedinghoff, 1994). Such a broad definition should pose little problem for the integration of IP rights envisaged by the Directive, whereby repertories can voluntarily be aggregated to reduce the numbers of licenses users need for multi-repertory and multi-territory service. Such aggregation has clear implications for online broadcasting, since Whereas 48 of the Directive calls for separate licensing for broadcasting on radio or television or broadcasting online.

(48)"Broadcasting organisations generally rely on a licence from a local collective management organisation for their own broadcasts of television and radio programmes which include musical works. That licence is often limited to broadcasting activities. A licence for online rights in musical works would be required in order to allow such television or radio broadcasts to be also available online". 


\section{Conclusion and proposals for more flexibility}

After years of frustration trying to combat piracy in Europe, the EU Commission with its latest Directive on IP rights management opens up a new line of attack aimed not at penalising IP rights violations but rather at offering legal alternatives to piracy to users and a new generation of agents and intermediaries in the digital content market. The reforms stipulated in this Directive follow many of the trends already seen in several countries that have adopted new ways of regulating IP in an effort to avoid suppressing creativity for the sake of reducing piracy. Collective experience with these laws has led, in my opinion, to a shift towards favouring new business models for content sharing in the EU, the latest expression of which is the new Directive 2014/26.

The Directive liberalises several aspects of the negotiating, licensing and exploitation of IP rights. The impact is likely to be considerable on the rigid system of collective management agencies in Spain. The Directive also stipulates a new way to manage multiterritorial licences for music creation, which will also apply to audiovisual works that include music, such as videogames and movies. These liberalising measures will render numerous creative industries more dynamic and adaptable in the face of exponentially changing technology for content generation and dissemination. The measures will also provide additional freedom from monopolies to producers and distributors of on-line music, movies and news, allowing innovators to sell, rent, or licence their IP rights as they wish.

I further argue that the Directive will be a catalyst throughout the digital entertainment sector because it will promote a more equitable compensation regime for IP creators and artists, and create a more flexible contractual framework for content intermediaries, such as Netflix, Spotify and Filmin, Pandora, Netflix and Amazon Prime.The Directive should create more collaboration and data sharing among IP stakeholders. IP organisations, independent agencies and law offices will need to interact and exchange information constantly. The Directive lays the groundwork for guaranteeing the mobility of services and content between different devices and different national networks when users move around Europe. This will make available to users a much greater amount of online content (film, TV series, documentaries) than the small amount available today.

I hope that these reforms will force Spanish IP law to change as well, since such liberalisation does not exist in the current collective management system. The winds of change are clearly coming, and already the Spanish system is showing a willingness to question "business as usual", as reflected in above referred NCC documents. The recently amended Spanish IP Law of November 2014, which enters into force in January 2015, stipulates a "single window" nationwide for invoicing for licences and rights. The fees charged by IP management agencies are also likely to undergo reform

soon. The lessons learned from these changes in 2015 and 2016 may prove applicable to the unified single digital market.

As the NCC reported in 2009, the Spanish IP Law restricts competition and reinforces entry barriers to IP rights beyond intrinsic financial barriers, reinforcing the tendency 
for a few IP stakeholders to control the market. This is a particular problem in the music and entertainment market. Liberalising the management and licensing of those IP rights currently required to be collectively managed is crucial to creating a digital single market, particularly in film.

In parallel with the liberalisation of how collective agencies function, which lies at the core of the major changes that the Directive will bring to Spain and other countries with similarly restrictive IP laws, I recommend the following reforms in Spain as we move towards a unified European digital market:

1. Competition among European companies should be promoted.

2. The current requirement of two-year contracts between rightholders and management agencies (CEDRO) or five-year contracts (DAMA, SGAE), without the possibility of early anulment, should be relaxed.

3. The geographic reach of contracts, as well as the types of works that fall under their jurisdiction, should be relaxed, including some kind of "work or territory reservations"

4. "Digital commerce" would be favoured if the exclusivity granted by rightholders to management agencies were relaxed to allow the rightholder (author, producer or artist) to simultaneously grant licences to third parties.

5. Individual IP rights management should be allowed.

6. Special price setting for non-commercial uses and for use by non-profit cultural entities, a possibility not currently contemplated in Spanish law, should be developed in accord with the European Commission's recommendations for changes needed in the digital market. 


\section{References}

Allendesalazar, R y Vallina, R. (2005), "Collecting Societies: The Usual Suspects" European Competition Law Annual 2005. The Interaction between Competition Law and Intellectual Property Law, Hart Publishing, UK.

Corredoira, L., Sood, S. (2015), Meeting new Readers through a Digital Transition: Lessons from the Entertainment industry. El Profesional de la Información, 2015, marzo, v. 24, n. 2. eISSN: 1699-2407 It will be available at http://www.elprofesionaldelainformacion.com/contenidos.html

Barron, A. (2011), Graduated Response' à L'Anglaise: Online Copyright Infringement and the Digital Economy Act (U.K.) 2010, Journal of Media Law, 3(2), pp. 305-347. Available at SSRN: http://ssrn.com/abstract $=1979495$

Dans, E. (2014 March). It's just a question of availability and price. IE Business School Blog, at www.medium.com .

Einhorn, M. A. (2002) "Intellectual Property and Antitrust: Music Performing Rights in Broadcasting", Columbia Journal for Law and the Arts.

European Commission (2005), Study on a Community Initiative on the CrossBorder Collective Management of Copyright,

European Commission(2008), Monitoring of the 2005 Music Online Recommendation, Brussels.

European Commission. (2013). Licences for Europe: fostering access and distribution of culture in the digital age. Press release: http://europa.eu/rapid/pressrelease_SPEECH-13-918_en.htm. Brussels: European Commission.

European Commission. (2012). On content in the Digital Single Market. Brussels, 18.12.2012: COM 2012, (789 final) .

Garcia Torres, E. E., \& Al, e. (2013). Supervivencia del periodismo en la era postdigital. Madrid-Valencia: Ministerio Ciencia y Competitividad, Spanish Gov.

Gervais, D.J. (2001) Internationalization of intellectual property: New challenges from the very old and the very new, Fordham Intell. Prop. Media \&Ent. LJ, 2001.

Guibault, L. Stef van Gompel (2010), Collective management in the European Union Amsterdam 2010Chapter 5, Daniel Gervais (ed.), Alphen aan den Rijn: Kluwer Law International, 2010), Págs. 135-167. Available at UvA-DARE, the institutional repository of the University of Amsterdam (UvA)http://hdl.handle.net/11245/2.106092

Handke, C. y Towse, R. (2007), "Economics of Copyright Collecting Societies", International Review of Intellectual Property and Competition Law, Vol. 38, No.8.

Hargreaves, I. (2011). "Hargreaves Review of Intellectual Property and Growth, or Digital Opportunity - A review of Intellectual Property and Grow”. London: 
https://www.gov.uk/government/uploads/system/uploads/attachment_data/file/32563/ip review-finalreport.pdf.

J., Smedinghoff (1994). "The Software". Legal Guide to MultimediaTechnology and entertainment convergent 2009: hot business and legal issues in Technotaiment (págs. 45-47). New York: Practising Law Institute.

Jenny, F. y Newman, P. G. (2005), "EC Competition Law Enforcement and Collecting Societies for Music Rights: What are we aiming for?" European Competition Law Annual 2005. The Interaction between Competition Law and Intellectual Property Law, Hart Publishing, United Kingdom

Katz, A. (2005), "The Potential Demise of Another Natural Monopoly:

Rethinking the Collective Administration of Performing Rights", Journal of Competition Law and Economics, Vol. 1, No. 3.

Marín López, J. (2007). “Artículo 153”. Comentarios a la Ley de Propiedad Intelectual. Madrid: La Ley.

Minero, G (2012), “Análisis comparado de las soluciones normativa y jurisdiccionales para la lucha frente a la piratería en Internet en España y en los países de nuestro entorno", Libertad de Expresión e información en Internet, Corredoira/Cotino Co-dirs, Madrid: Centro de Estudios Políticos y Constitucionales (págs. 215-228)

Ordóñez Solís, D. (2011). "Las descargas ilegales en Internet: el contexto jurídico europeo de la Ley Sinde", Revista Aranzadi Unión Europea, XXXVII, no. 11.

Ramón, F. (2012), "Derecho de cita, plagio e Internet", Libertad de Expresión e información en Internet, Corredoira/Cotino Co-dirs, Madrid: Centro de Estudios Políticos y Constitucionales (págs. 233-258)

Picard, R., \& De los Angeles, J. (2014). "Managing Creativity and Diversity". IMMAA Conference. Pamplona: Available at: www.unav.es/IMMAA.

PriceWaterhouse Cooper (2013), "Outlook for the global sports market about incomes, media rights and sport internationalization". Available here.

Sood, Sanjay; Corredoira, Loreto (2015)

The Impact of Digital Technologies on the Paid Content Market. The Netflix paradigm IESE Publishing, Technical Note, MN-384-E, March, 2015, http://www.iesep.com/en/catalogsearch/advanced/result/?area[]=133

Stamatoudi, I. (2002). "Copyright and Multimedia Works: A Comparative Analysis”.Port Chester, NY, USA: Cambridge University Press. 
TorrentFreak.com Most pirated movies in 2013, source: http://torrentfreak.com/thehobbit-most-pirated-film-of-2013-131231

Villanueva, J. C. (2014). "Paid-content Distribution in the Entertainment Industry”. Los Angeles: UCLA Research Project.

Vinje, T., \& Nllranen, O. (2005). "The Application of Competition Law to Collecting Societies". European Competition Law .

Waldfogel, D. a. (2012). "Reel Piracy: The effect of Online Film Piracy on International Box Office Sales". Available at http://ssrn.com/abstract $=1986299$

\section{LEGAL AND OFFICIAL REFERENCES}

AEVAL - Agencia Estatal de Evaluación de las Políticas Públicas y la Calidad de los Servicios (2008) Evaluación del Sistema de Gestión Colectiva de los Derechos de Propiedad Intelectual, Madrid.

Berne Convention for the Protection of Literary and Artistic Works, of September 9, 1886, completed at PARIS on May 4, 1896, revised at BERLIN on November 13, 1908, completed at BERNE on March 20, 1914, revised at ROME on June 2, 1928, at BRUSSELS on June 26, 1948, at STOCKHOLM on July 14, 1967, and at PARIS on July 24, 1971, and amended on September 28, 1979.

Code de la propriété intellectuelle (France) Version consolidée au 14 novembre 2014.

Communication from the Commission, On content in the Digital Single Market, Brussels, 18.12.2012 COM(2012) 789 final

Copyright Law of the United States of America and Related Laws Contained in Title 17 of the United States Code, December 2011

Council Directive92/100/EEC of 19 November 1992 on rental right and lending right and on certain rights related to copyright in the field of intellectual property

Directive 93/83/EEC of the European Parliament and of the Council of 27 September 1993 on the coordination of certain rules concerning copyright and rights related to copyright applicable to satellite broadcasting and cable retransmission: "Member States shall ensure that the right of copyright owners and holders or related rights to grant or refuse authorization to a cable operator for a cable retransmission may be exercised only through a collecting society".

Directive 2004/48/EC of the European Parliament and of the Council of 29 April 2004 on the enforcement of intellectual property rights / Corrigendum to Directive 2004/48/EC of the European Parliament and of the Council of 29 April 2004 on the enforcement of intellectual property rights, Official Journal of the European Union L 157 of 30 April 2004. 
Directive 2014/26/EU of the European Parliament and of the Council of 26 February 2014 on collective management of copyright and related rights and multi-territorial licensing of rights in musical works for online use in the internal market Text with EEA relevance

European Commission, "Licences for Euro stakeholder dialogue”, Memo, Brussels, 13 November, 2013

European Commission, "The Compact for Growth and Jobs: one year on”, June 2013

France Law: Section 2. Proprieté Intellectuel Code: Haute Autorité piur la diffusion des oeuvres et la protection des droits sur Internet Paragraphe 2 : La commission de protection des droits/ Article R331-6

The Hargreaves Review of Intellectual Property: Where next?" Available at (Visited on Nov. 28th)

http://www.publications.parliament.uk/pa/cm201213/cmselect/cmbis/367/367.pdf

UK Copyright, Designs and Patents Act 1988 Available at (Visited on Nov. 28th) http://www.legislation.gov.uk/ukpga/1988/48/contents

Spanish Law of Sostenible Economy, passed by Law 2/2011 of March $4^{\text {th }}$

Commissioner Michel BARNIER Speech, Initiative « des licences pour l'Europe » : des engagements concrets pour améliorerl'accès des européens aux contenussur internet Available at (Visited on Nov. 28th) http://europa.eu/rapid/press-release_SPEECH-13919_fr.pdf

Lei $\mathrm{n}^{\mathrm{o}}$ 12.965, de 23 de abril de 2014 (Brazil); available at (visitedon January 2015) http://www.planalto.gov.br/CCIVIL_03/_Ato2011-2014/2014/Lei/L12965.htm.

National Commission on Competition of Spain (2009), NCC Comisión Nacional de la Competencia, Informe sobre la Gestión Colectiva de derechos de Propiedad Intelectual,ReleasedJanuary 2010, Url: cncompetencia.es . Spanish versión Comisión Nacional de la Competencia, Informe sobre la Gestión Colectiva de derechos de Propiedad Intelectual, 2009, Url: cncompetencia.es

Spanish IP Law: Real Decreto Legislativo 1/1996, de 12 de abril, por el que se aprueba el texto refundido de la Ley de Propiedad Intelectual, regularizando, aclarando y armonizando las disposiciones legales vigentes sobre la materia. «BOE» núm. 97, de 22/04/199, Documento consolidado BOE-A-1996-8930 después reforma 2014.

Available at (Visitedon Nov. 28th) https://www.boe.es/buscar/pdf/1996/BOE-A-19968930-consolidado.pdf

Spanish IP Reform passed by Law 21/2014 of November 4th, modifying Spanish IP Law . BOE /11/2014.

Spanish Law of Sustainable Economy, passed by Law 2/2011 of March $4^{\text {th }}$

WIPO - World Intellectual Property Organization (2007), Collective Management of Copyright and Related Rights, Switzerland 


\section{FIGURES AND TABLE}

\section{Figure 1.}

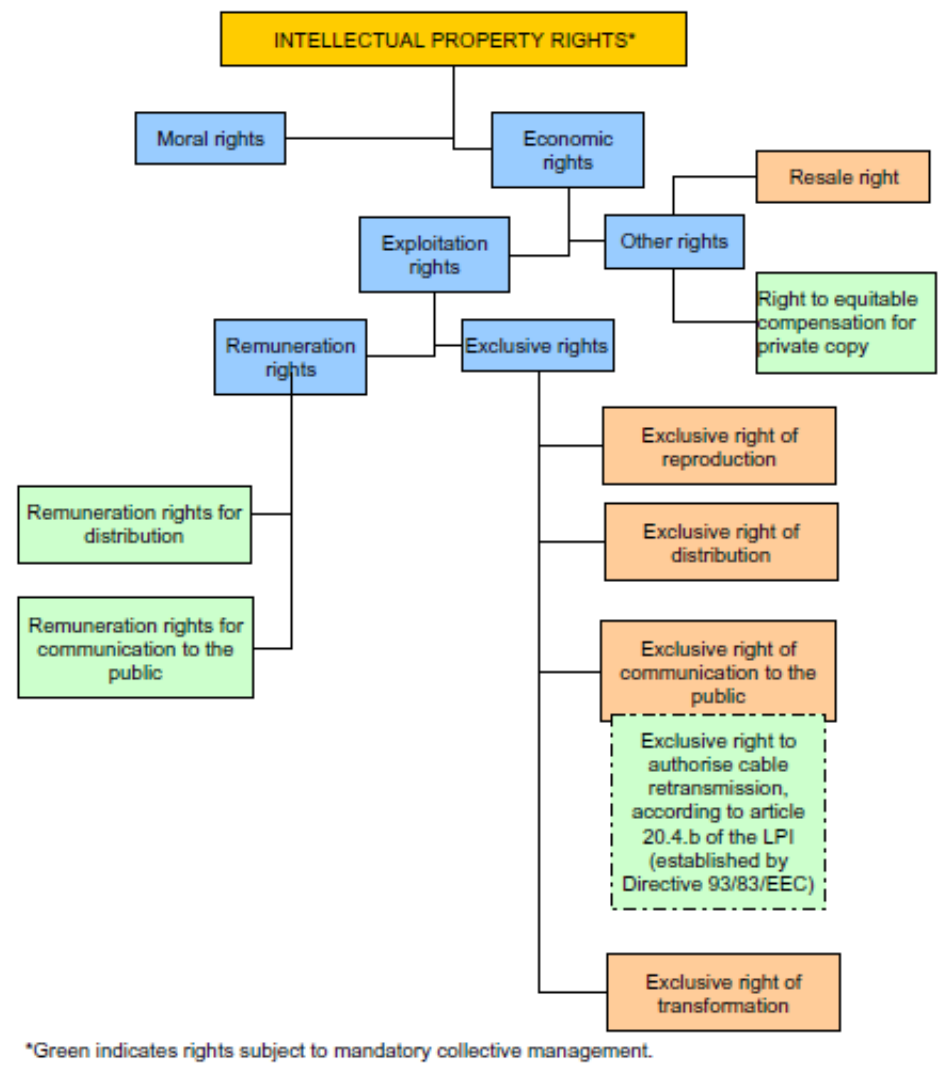

FIGURE 1 legend. Various IP rights for authors, artists/performancers and producers. In Spain, the rights shown in green boxes must be collectively managed through licensed agencies. Source: CNC 2009:18. 


\begin{tabular}{|c|c|c|}
\hline Name & Jurisdiction & Current status \\
\hline LoiHadopi & France & $\begin{array}{l}\text { Enacted, found to be unconstitutional in } \\
\text { June } 2009 \text {, subsequently revised by the } \\
\text { Constitutional Council Decision no. 2009- } \\
580 \text { of } 10 \text { June } 2009 \\
\text { Reviewed in June } 2013 \text {, modified }\end{array}$ \\
\hline $\begin{array}{l}\text { Ley \& Reglamento Sinde- } \\
\text { Wert }\end{array}$ & Spain & Enacted \\
\hline Digital EconomyAct & UK & Enacted \\
\hline $\begin{array}{l}\text { Internet Law (Marco Civil da } \\
\text { Internet }^{31} \text { ) }\end{array}$ & Brazil & Enacted \\
\hline Ley Lleras & Colombia & In process \\
\hline SOPA and PIPA & US & Rejected \\
\hline
\end{tabular}

Table 2. IP rights for audiovisual work in Spain

\begin{tabular}{|l|l|l|l|}
\hline \multirow{2}{*}{ Rights } & Rightholder & Artist/performer & Producer \\
\cline { 2 - 4 } & Author & $\begin{array}{l}\text { Related rights: } \\
\text { Moral rights } \\
\text { Economic rights } \\
\text { Remuneration rights }\end{array}$ & $\begin{array}{l}\text { Economic rights } \\
\text { Remuneration } \\
\text { rights }\end{array}$ \\
\hline $\begin{array}{l}\text { Objects } \\
\text { affected }\end{array}$ & $\begin{array}{l}\text { Audiovisual works } \\
\text { (e.g. film, shortfilm, } \\
\text { documentary) }\end{array}$ & Performance & $\begin{array}{l}\text { Audiovisual } \\
\text { recordings }\end{array}$ \\
\hline
\end{tabular}


Table 3. IP rights that must be managed collectively under Spanish law and rights that can be managed individually

\begin{tabular}{|c|c|}
\hline Mandatory Collective Management & Individual or Free Management \\
\hline $\begin{array}{ll}\text { - } & \text { Right to remuneration for distribution } \\
\text { - } & \text { Right to remuneration for public } \\
\text { communication } \\
\text { - }\end{array}$ & $\begin{array}{l}\text { - Right of fixation } \\
\text { - Right of reproduction } \\
\text { - Right of communication to the public } \\
\text { (cable transmission is excluded in } \\
\text { Directive 2014/26) } \\
\text { Right of transformation }\end{array}$ \\
\hline
\end{tabular}

\section{Table 4. Collective management entities, by type of creative content creator or producer}

Collecting Societies for Authors

SGAE

DAMA

Collecting Societies for Producers

EGEDA

AGEDI

Collecting Societies for Artists

\begin{tabular}{|l|}
\hline AISGE \\
\hline AI \\
\hline VEGAP \\
\hline
\end{tabular}

Collecting Societies for Publishers

CEDRO

Keywords. EU Copyright Directives, Collective societies, IP Laws, multiterritorial licences, online services, Single Market, Content distribution 


\title{
FOOTNOTES
}

\begin{abstract}
${ }^{1}$ Directive 2014/26/EU of the European Parliament and of the Council of 26 February 2014 on collective management of copyright and related rights and multi-territorial licensing of rights in musical works for online use in the internal market Text with EEA relevanceAvailable herehttp://eur-lex.europa.eu/legalcontent/EN/TXT/?uri=uriserv:OJ.L_.2014.084.01.0072.01.ENG
\end{abstract}

${ }^{2}$ DAE. European Commission's Digital Agenda for Europe, launched in May 2010. Available at: http://ec.europa.eu/digital-agenda/digital-agenda-europe

${ }^{3}$ Communication from the Commission, On content in the Digital Single Market, Brussels, 18.12.2012 $\operatorname{COM}(2012) 789$ final

${ }^{4}$ Sood, S., Corredoira, L., García-Ugellés, A.

${ }^{5}$ European Commission, "Licences for Euro stakeholder dialogue”, Memo, Brussels, 13 November, 2013

${ }^{6}$ European Commission, “The Compact for Growth and Jobs: one year on”, June 2013, Available at http://ec.europa.eu/europe2020/pdf/compact_en.pdf

${ }^{7}$ Copyright Law of the United States of America and Related Laws Contained in Title 17 of the United States Code, December 2011, Available at (Visited on Nov. 28th) http://copyright.gov/title17/92preface.html A Complete version of the U.S. Copyright Law, December 2011 (PDF format) also at http://copyright.gov/title17/circ92.pdf

${ }^{8}$ Berne Conventionfor the Protection of Literary and Artistic Works, of September 9, 1886, completed at PARIS on May 4, 1896, revised at BERLIN on November 13, 1908, completed at BERNE on March 20, 1914, revised at ROME on June 2, 1928, at BRUSSELS on June 26, 1948, at STOCKHOLM on July 14, 1967, and at PARIS on July 24, 1971, and amended on September 28, 1979. URL (Visited on Nov. 28th) http://www.wipo.int/treaties/en/text.jsp?file_id=283698

${ }^{9}$ Code de la propriétéintellectuelleVersion consolidée au 14 novembre 2014, Available at (Visited on Nov. 28th) httphttp://www.legifrance.gouv.fr/affichCode.do?cidTexte=LEGITEXT000006069414

\footnotetext{
${ }^{10}$ Spanish IP Law: Real Decreto Legislativo 1/1996, de 12 de abril, por el que se aprueba el texto refundido de la Ley de Propiedad Intelectual, regularizando, aclarando y armonizando las disposiciones legales vigentes sobre la materia. «BOE» núm. 97, de 22/04/199, Documento consolidado BOE-A-19968930 después reforma 2014. Available at (Visited on Nov. 28th) https://www.boe.es/buscar/pdf/1996/BOE-A-1996-8930-consolidado.pdf

${ }^{11}$ See http://eur-lex.europa.eu/LexUriServ/LexUriServ.do?uri=CELEX:32007L0065:en:NOT

${ }^{12}$ Corrigendum to Directive 2004/48/EC of the European Parliament and of the Council of 29 April 2004 on the enforcement of intellectual property rights, Official Journal of the European Union L 157 of 30 April 2004.
}

${ }^{13}$ Ordóñez Solís, D. (2011). "Las descargas ilegales en Internet: el contexto jurídico europeo de la Ley Sinde", Revista Aranzadi Unión Europea, XXXVII, no. 11, p. 12.

${ }^{14}$ Minero, G. (2013)."Análisis comparado de las soluciones normativas y jurisdiccionales para la lucha frente a la piratería en Internet en España y los países de nuestro entorno". In Corredoira, L and Cotino, L. (2013). Libertad de expresión y de información en Internet, Centro de Estudios Políticos y

Constitucionales, Madrid, pp. 215-232. 
${ }^{15}$ Barron, A. (2011) "'Graduated Response'à L'Anglaise: Online Copyright Infringement and the Digital Economy Act (U.K.) 2010", Journal of Media Law, 3(2), pp. 305-347. Available at SSRN:

http://ssrn.com/abstract=1979495

${ }^{16}$ The so-called "Google tax" or the remuneration right for news aggregation was recently approved in Spain as a modification of Article 32.2. of the Int. Property Law (passed by Law 21/2014 of November $5^{\text {th }}$ to modifying IP Law Royal Decree 1/1996)" Article 32.2.

${ }^{17}$ The Hargreaves Review of Intellectual Property ${ }^{17}$ : Where next?" Available at (Visited on Nov. 28th) http://www.publications.parliament.uk/pa/cm201213/cmselect/cmbis/367/367.pdf

${ }^{18}$ Copyright, Designs and Patents Act 1988 Available at (Visited on Nov. 28th) http://www.legislation.gov.uk/ukpga/1988/48/contents

${ }^{19}$ Section 2. Proprieté Intellectuel Code: Haute Autorité piur la diffusion des oeuvres et la protection des droits sur Internet Section 2 ProprietéIntellectuelCode : Haute Autoritépour la diffusion des œuvres et la protection des droits sur internet/ Paragraphe 2 : La commission de protection des droits/ Article R331-6 En savoir plus sur cetarticle...Modifié par Décret n²009-1773 du 29 décembre 2009 - art. 2

${ }^{20}$ Spanish Law of Sustainable Economy, passed by Law 2/2011 of March $4^{\text {th }}$

${ }^{21}$ Commissioner Michel BARNIER Speech, Initiative « des licences pour l'Europe » : des engagements concrets pour améliorer l'accès des européens aux contenussur internet Available at (Visited on Nov. 28th) http://europa.eu/rapid/press-release_SPEECH-13-919_fr.pdf

${ }^{22}$ In the Spanish IP Law in particular the collective societies are regulated under TÍTULO IV. Las entidades de gestión de los derechos reconocidos en la Ley (art. 147 to 159)

${ }^{23}$ National Commission on Competition of Spain (2009), NCC Comisión Nacional de la Competencia, Informe sobre la Gestión Colectiva de derechos de Propiedad Intelectual, ReleasedJanuary 2010, Url: cncompetencia.es

${ }^{24}$ UTECA, Varios autores (2009) "Legislación aplicable a las tarifas por utilización de obras protegidas en televisión, Casos Telecinco y Sogecable”, en Libro Verde de la Televisión UTECA, Bilbao: Ediciones Deusto.

${ }^{25}$ A reform has been passed recently by Law 21/2014 of November 4th, modifying Spanish IP Law . BOE 5/11/2014.

${ }^{26}$ The imposition of the collective management obligation for the exclusive right to authorise cable retransmission stems from a European Union Directive. Specifically, as indicated in article 9.1 of Directive 93/83/EEC of the European Parliament and of the Council of 27 September 1993 on the coordination of certain rules concerning copyright and rights related to copyright applicable to satellite broadcasting and cable retransmission: "Member States shall ensure that the right of copyright owners and holders or related rights to grant or refuse authorization to a cable operator for a cable retransmission may be exercised only through a collecting society”.

${ }^{27}$ Communication from the Commission, On content in the Digital Single Market, Brussels, 18.12.2012 $\operatorname{COM}(2012) 789$ final, p. 4

${ }^{28}$ Council Directive No. 92/100/EEC of 19 November 1992 on rental right and lending right and on certain rights related to copyright in the field of intellectual property, Council Directive 93/83/EEC of 27 September 1993 on the coordination of certain rules concerning copyright and rights related to copyright applicable to satellite broadcasting and cable retransmission.

${ }^{29}$ Diario "El país", "Solidaridad a beneficio de la SGAE”, Available at elpais.com 20/05/2009 
${ }^{30}$ Copyright Registration for Multimedia Works http://copyright.gov/circs/circ55.pdf

${ }^{31}$ Lei n ${ }^{\circ}$ 12.965, de 23 de abril de 2014; available at http://www.planalto.gov.br/CCIVIL_03/_Ato20112014/2014/Lei/L12965.htm. See also URL http://culturadigital.br/marcocivil/ 